\title{
PALM2/AKAP2 Fusion Protein
}

National Cancer Institute

\section{Source}

National Cancer Institute. PALM2/AKAP2 Fusion Protein. NCI Thesaurus. Code C158488.

PALM2/AKAP2 fusion protein (1103 aa, $122 \mathrm{kDa}$ ) is encoded by the human

PALM2/AKAP2 fusion gene. This protein plays a role in the determination of human height. 